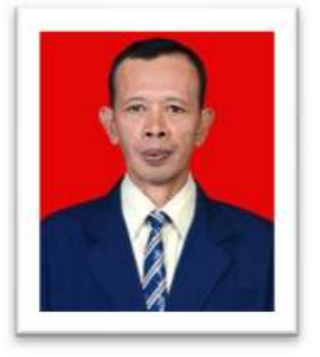

\title{
FOREWORD BY EDITOR IN CHIEF
}

The International Conference on Da'wa and Communication (ICON-DAC) 2019 was the first conference on da'wa and communication organized by the Da'wa and Communication Faculty, State Islamic University (UIN) of Sunan Ampel Surabaya, Indonesia. This conference was held on September 24-26, 2019, in Surabaya, Indonesia.

ICON-DAC 2019 sets the theme "Da'wa and Civilized Communication: Pious, Peaceful, Enlightening". This theme is divided into 13 topical scopes and 1 additional scope, namely:

1. Da'wa for Building Social Harmony and Civilization,

2. Da'wa and the Challenge of Millennium Era,

3. Digital Culture and Islamic Communication,

4. Da'wa and Politics in South East Asia,

5. Islam and Identity in Social Media,

6. Da'wa Strategy based on Local Wisdom in South East Asia,

7. Walisongo as a Model of Successful Da'wa,

8. Da'wa and Community Engagement,

9. Counseling, Psychotherapy and Islamic Healing in South East Asia,

10. Masjid as a Center for the Great Islamic Civilization,

11. Gender Mainstreaming in Da'wa,

12. Peaceful Journalism as a Tool of Da'wa,

13. Islamic Institution and Its Social and Economic Roles,

14. Additional.

ICON-DAC 2019 received contributions from keynote speakers and presenters from five countries; Indonesia, Malaysia, Australia, Egypt, and Germany. Keynote speakers come from four countries. They are (1) Prof. Dr. Phil. H. Kamaruddin Amin, MA (General Director of Islamic Education of Indonesian Ministry of Religious Affairs), (2) Prof. Dr. H. Nur Syam, M.Si (Da'wa dan Communication Faculty, UIN Sunan Ampel, Indonesia), (3) Prof. Muhammad Reevany Bustami, Ph.D (Centre for Policy Research \& International Studies, Universiti Sains Malaysia, Penang), (4) Prof. Dr. H. Moh. Ali Aziz, M.Ag (Da'wa dan Communication Faculty, UIN Sunan Ampel, Indonesia), (5) Prof. Nadirsyah Hosen, Ph.D (Faculty of Law, Monash University, Australia), (6) Shaykh Dr. Muhammad Husaini Farg Sayyid Ahmad, Al-Azhar University, Egypt, (7) Dr. Phil. Hermin Indah Wahyuni, S.IP, M.Si. (Director of Center for Southeast Asian Social Studies, Gadjah Mada University Yogyakarta, Indonesia). This contribution was captured through open publications on the ICON-DAC website and social media in the forms of Whatsapp, Facebook, and Twitter, as well as institutional networks between universities.

The current of enthusiasts as presenters came from 22 universities, in Indonesia and abroad, with 56 presenters. From the environment of UIN Sunan Ampel Surabaya, the presenters came from Fakultas Dakwah dan Komunikasi (FDK), Fakultas Adab dan Humaniora (FAH), Fakultas Syariah dan Hukum (FSH), dan Fakultas Ekonomi dan Bisnis Islam (FEBI). Some of them are students from Malaysia. In addition, the presenters came from 21 universities, namely: (1) Southeast Asian Studies at Johann Wolfgang Goethe-Universität, Germany, (2) UIN Syarif Hidayatullah Jakarta, (3) UIN Antasari Banjarmasin, (4) UIN Raden Fatah Palembang, (5) Fakultas Dakwah dan Komunikasi UIN Alauddin Makassar, (6) IAIN Sultan Amai Gorontalo, (7) Fakultas 
Ushuluddin, Adab, dan Dakwah IAIN Parepare, (8) Jurusan Dakwah IAIN Bengkulu, (9) IAIN Jember, (10) IAIN Samarinda, (11) IAIN Tulungagung, (12) IAIN Madura, (13) IDIA (Institut Dirosat Islamiyah) Prenduan, (14) IAI Ibrahimy Banyuwangi, (15) Institut Agama Islam Syarifuddin, Lumajang, (16) STAI Bustanul Ulum Lumajang, (17) UNUJA Probolinggo, (18) State University of Malang, (19) INSURI (Institut Agama Islam Sunan Giri) Ponorogo, (20) Prodi BKI Fakultas Dakwah IAIN Purwokerto, dan (21) Jurusan BKI Fakultas Dakwah UIN Sultan Maulana Hasanuddin Banten. Among 56 presenters, 34 presenters (61\%) came from UIN Sunan Ampel Surabaya and 22 presenters (39\%) came from outside.

The presenters paid attention to the fields of study according to their expertise and were adapted to the choice of scope that was available as explained above. The description can be seen in the table below.

\section{Table 1. Description of the Number of Papers Based on Scopes}

\begin{tabular}{|l|c|c|}
\hline \multicolumn{1}{|c|}{ Scopes } & Amount & $\mathbf{9}$ \\
\hline 1. Da'wa for Building Social Harmony and Civilization & 7 & $11,7 \%$ \\
\hline 2. Da'wa and the Challenge of Millennium Era & 8 & $13,3 \%$ \\
\hline 3. Digital Culture and Islamic Communication & 2 & $3,3 \%$ \\
\hline 4. Da'wa and Politics in South East Asia & 0 & $0,0 \%$ \\
\hline 5. Islam and Identity in Social Media & 2 & $3,3 \%$ \\
\hline 6. Da'wa Strategy Based on Local Wisdom in South East Asia & 9 & $15,0 \%$ \\
\hline 7. Walisongo as a Model of Successful Da'wa & 1 & $1,7 \%$ \\
\hline 8. Da'wa and Community Engagement & 7 & $11,7 \%$ \\
\hline 9. Counseling, Psychotherapy and Islamic Healing in South East Asia & 12 & $20,0 \%$ \\
\hline 10. Masjid as a Center for the Great Islamic Civilization & 4 & $6,7 \%$ \\
\hline 11. Gender Mainstreaming in Da'wa & 4 & $6,7 \%$ \\
\hline 12. Peaceful Journalism as a Tool of Da'wa & 0 & $0,0 \%$ \\
\hline 13. Islamic Institution and Its Social and Economic Roles & 0 & $0,0 \%$ \\
\hline 14. Additional & 4 & $6,7 \%$ \\
\hline Amount & $\mathbf{6 0}$ & $\mathbf{1 0 0 , 0 \%}$ \\
\hline
\end{tabular}

Source: ICON-DAC Review, 2019.

The table above gives a description of the current rating of scopes of study by presenters. The highest ranking was achieved by scope of "Counseling, Psychotherapy and Islamic Healing in South East Asia" (code 9) with 12 papers (20\%). The second ranking was achieved by the scope of "Da'wa Strategy Based on Local Wisdom in South East Asia" (code 6) with 9 papers (15\%). While the lowest ranking was achieved by the scopes of "Da'wa and Politics in South East Asia" (code 4), "Peaceful Journalism as a Tool of Da'wa" (code 12), and "Islamic Institution and Its Social and Economic Roles" (code 13) with 0 papers (0\%) for each scope.

There were 56 full papers of 14 scopes. They were examined and selected in accordance with its academic eligibility for an international proceeding. The result of selection is 43 presentation papers published within this proceeding. They were written in multilanguages; 14 English papers, 2 Arabic papers, and 27 Indonesian papers. These papers spread into 11 of 14 scopes, beyond scopes 4,12 , and 13 which do not contain any papers. They were also enriched by three papers of keynote speakers, namely: (1) "Re-assessing the Development of Da'wa Science: Da'wa Study in Academic Work Discourse” by Prof. Dr. Nur Syam, M.Si (Da'wa and Communication Faculty, UIN Sunan Ampel), (2) "Challenging Traditional Islamic Authority: The Impact of Social Media in Indonesia" by Prof. Nadirsyah Hosen, Ph.D (Faculty of Law, Monash University, Australia), and (3) "Kiai and Adherents Relations in the Contemporary Commodification" 
by Prof. Dr. Moh. Ali Aziz, M.Ag (Da'wa and Communication Faculty, UIN Sunan Ampel). So, amount of the papers are 46.

In addition, among those 46 papers, there were two papers will be published by the Journal of Islamic Communication/Jurnal Komunikasi Islam (JKI) on its December 2019 publication edition. This Journal was published by the Da'wa and Communication Faculty, State Islamic University of Sunan Ampel Surabaya. Those two papers were: (1) Preferensi Penggunaan Media Sosial terhadap Keberagamaan Remaja (paper 7) written by Nila Audini Oktavia and Ellyda Retpitasari (Students of Postgraduate, State Islamic University of Sunan Ampel) and (2) Challenges of Da'wa in the Digital Era: Da'wa Phenomena on Instagram (paper 29) written by Sukma Ari Ragil Putri and Luthfi Ulfa Ni'amah (State Islamic Institute of Tulungagung). So, amount of the papers published in this proceeding is 44 .

Finally, this proceeding is a sign of academic dynamics as a result of the ICON-DAC 2019. This event was a historical first stone that was important for the periods of its events in the future. Therefore, the contributions of the keynote speakers and presenters can be valued in the history as a jariyah (finality investment). The reviewer team and the entire committee, institutionally appreciate their contributions with all thanks to Allah SWT. Hopefully it will provide optimal benefits for the world of science, especially for the science of da'wa and communication studies.

Surabaya, September 27, 2019

Editor in Chief,

Dr. Sokhi Huda, M.Ag 